\title{
[特別講演 II]
}

\section{臨床検査よりみた抗生物質療法}

\author{
小酒井望（順大臨床病理）
}

医学, 医療の進歩にともない，感染症は変貌しつつあ る. とくに細菌感染症の変貌は著るしく, 原因菌として のグラム陽性球菌の比率は減少し,グラム陰性桿菌の割 合いが増加しつつある。しかもこれらグラム陰性桿菌は 常用抗生物質に耐性のものが多い，病原菌の種類によつ て抗生物質に耐性になり易いものとなりにくいものがあ り，又薬剤の種類によつて菌が而性になり易いものとな りにくいものがある。しかし耐性になりにくいといって も長くその薬剤が使用されていると，いずれは耐性菌が 堌加する場合が少なくないしたがつて抗生物質療法に 際しては，各病原菌のそれぞれの抗生物質に対する感性 度, 感性率を熟知している必要がある。また最近弱毒菌

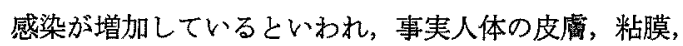
あるいは生活環境に常在する細菌による感染が目立つよ らになつた. 感染に対する抵抗力の低下した患者, 例え ば重篤な基礎疾患を持つ患者, あるい治浩, 赤断のた
め抵抗力が低下し，感染を受け易くなつた患者が増加し ている. かかる患者では病巣からの検查材料採取に当つ て，皮盧または粘膜の常在菌が混入した場合，原因菌方 どれか区別しにくいことが多い．

抗生物質潦法の発達, 普及した今日, 適正な抗生物質 療法こそが抢の扔のの抗生物質の寿命を長くし, 耐性菌 の蒙延を防ぎ，抗生物質の副作用を防ぐ所以である. 適 正な抗生物質療法を行うには，感染症の的確な病原診断 (原因微生物の検出), 抗生物質感受性検査, さらに副作 用チェックのための諸検查を行うべきは周知のことであ る.

私は病原診断と感受性検査を中心として，臨床検查の 立場から今日の抗生物質療法を検討しようと思う。

\section{1. 耳奥咽喉科領域の感染症の原因菌の变要}

順天堂医院中央臨床検查室へ提出された耳鼻咽喉科の 澧・分泌液 (耳をたはその周囲のものが大部分を占め

表 1 耳鼻㸶喉科領域の膿・分泌液加らの検出菌の変遷

\begin{tabular}{|c|c|c|c|c|c|c|}
\hline 菌 & $\begin{array}{r}1965 \\
66\end{array}$ & $\begin{array}{r}1967 \\
68\end{array}$ & $\begin{array}{r}1969 \\
70\end{array}$ & $\begin{array}{r}1971 \\
72\end{array}$ & $\begin{array}{r}1973 \\
74\end{array}$ & 計 \\
\hline 黄色ブドウ球菌 & 20.0 & 20.3 & 18.2 & 17.5 & 17.4 & 18.3 \\
\hline 表皮ブドウ球菌 & 10.8 & 16.8 & 14.3 & 13.1 & 12.2 & 13.5 \\
\hline 溶 血 連 鎖 球 菌 & 4.8 & 2.2 & 1.2 & 3.6 & 3.9 & 3.1 \\
\hline 肺 炎 球 菌 & 0.6 & 0.7 & 0.7 & 0.7 & 1.1 & 0.9 \\
\hline Corynebacterium & 3.6 & 4.0 & 7.6 & 7.6 & 8.9 & 7.0 \\
\hline 大 腸 & 1.9 & 0.4 & 0.8 & 1.0 & 1.2 & 1.0 \\
\hline Klebsiella & 2.1 & 2.2 & 2.5 & 3.9 & 2.9 & 2.8 \\
\hline Enterobacter & 1.1 & 1.3 & 1.3 & 1.9 & 2.0 & 1.7 \\
\hline Proteus 属 & 5.2 & 4.4 & 7.0 & 6.2 & 7.3 & 6.3 \\
\hline 緑＼cjkstart膿 & 17.6 & 16.2 & 16.8 & 11.5 & 10.0 & 13.2 \\
\hline Haemohilus & 1.1 & 0.8 & 2.2 & 5.1 & 7.7 & 4.5 \\
\hline 嫌 気 性 菌 & 3.5 & 3.2 & 2.5 & 5.8 & 4.7 & 4.1 \\
\hline Candida albicans & 1.1 & 2.6 & 2.1 & 1.3 & 2.2 & 2.0 \\
\hline Aspergillus & 1.6 & 8.5 & 8.0 & 3.0 & 1.9 & 4.4 \\
\hline 検 出 株 数 & 631 & 1,445 & 1,234 & 1,240 & 2,950 & 7,500 \\
\hline
\end{tabular}


る）の過去10年間の集計をみると，多種類の菌が分離さ れており，それらの菌種のほとんどが口腔・咽頭・鼻腔 などに常在するものである。主要菌種の推移を 2 年ごと に集計して観察すると表 1 のごとく, 黄色ブドウ 球 菌 (Staph. aureus) が最も多く，表皮ブドウ球菌（Staph. epidermidis), 緑膿菌 (Pseudomonas aeruginosa) がこ れについでいる，そして黄色ブドウ球菌，緑膿菌の比率 が次第に減少の傾向を示し, Corynebacterium, Proteus, 属, Haemophilus 属, Enterobacter は增加の傾向にあ る. Proteus 属の中では Pr. mirabilis が最も多く, Pr. inconstans (Providencia) がこれにつぐ. Haemophilus 属ではインフルエンザ菌 (H. influenzae) と H. parainfluenzae が大部分である. 化学療法発達以前（1940年以 前）には，急性中耳炎の原因菌の大部分は肺炎球菌，溶 血連鎖球菌で占められ，ブドウ球菌，インフルエンザ菌 は低率であつた の比率注著しく低い．また賞つては肺炎球菌の中で而型 (Streptococcus mucosus などといわれた) が優位を占め ていたが，今日では本菌型はまれである。

外科領域の膿 - 分泌液については, グラム陽性球菌が 減少し, グラム陰性桿菌が增加し,グラム陰性桿菌が優 位を占め，その傾向が年とともに強くなると言われる
表 2 耳悬咽喉科と外科領域に求ける膿・分泌液加 らの検出菌種の比較

$(1973 ， 1974 ， 2$ 年間の比較)

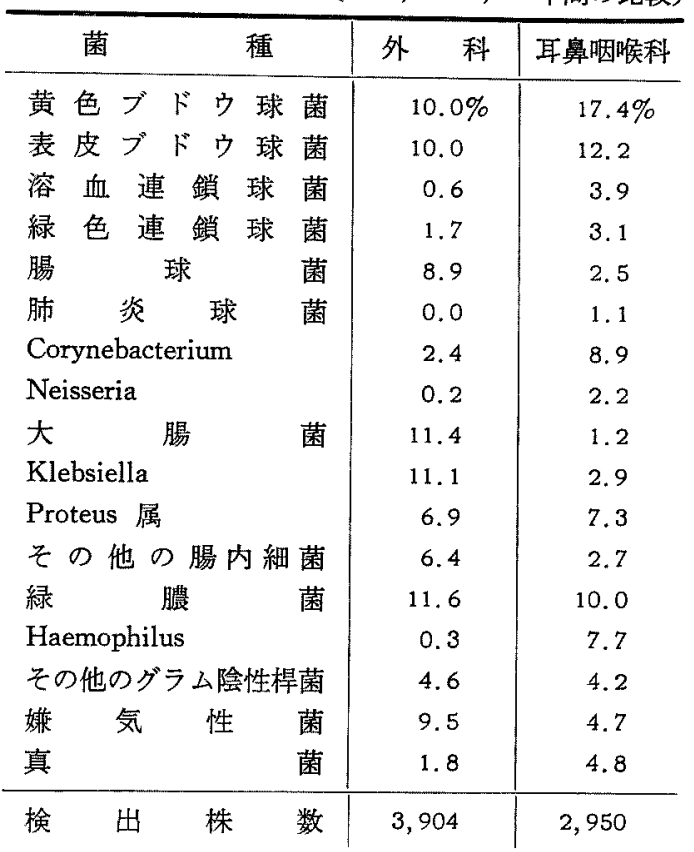

表 3 耳鼻咽喉科領域の膿・分泌液における病原菌の陽性率

\begin{tabular}{|c|c|c|c|c|c|c|c|c|c|}
\hline \multicolumn{2}{|c|}{ 年 } & \multicolumn{2}{|r|}{ 度 } & $\begin{array}{r}1965 \\
66\end{array}$ & $\begin{array}{r}1967 \\
68\end{array}$ & $\begin{array}{r}1969 \\
70\end{array}$ & $\begin{array}{r}1971 \\
72\end{array}$ & $\begin{array}{r}1973 \\
74\end{array}$ & 計 \\
\hline 険 & 佐 & 本 & 数 & 415 & 857 & 824 & 714 & 1,645 & 4,455 \\
\hline 陽 & 性 & 件 & 数 & $\begin{array}{c}358 \\
(86.3 \%)\end{array}$ & $\begin{array}{c}762 \\
(88.9 \%)\end{array}$ & $\begin{array}{c}683 \\
(82.9 \%)\end{array}$ & $\begin{array}{c}616 \\
(76.5 \%)\end{array}$ & $\begin{array}{c}1,425 \\
(86.6 \%)\end{array}$ & $\begin{array}{c}3,844 \\
(86.3 \%)\end{array}$ \\
\hline 混 & & 1 & 種 & $49.4^{*}$ & 46.1 & 47.1 & 39.3 & 45.1 & 45.1 \\
\hline 㚜 & & 2 & 種 & 30.2 & 31.2 & 32.2 & 32.5 & 30.0 & 31.1 \\
\hline 染 & & 3 & 種 & 13.9 & 15.2 & 14.1 & 14.9 & 16.3 & 15.2 \\
\hline 猋 & & & 種 & 4.2 & 5.5 & 4.7 & 6.5 & 6.2 & 5.6 \\
\hline 態 & & 5 種 & 以上 & 2.2 & 2.0 & 1.9 & 6.8 & 2.4 & 2.9 \\
\hline
\end{tabular}

*この欄の数字は陽性件数に対する百分率を示す

が，耳鼻咽喉科領域ではまだグラム陽性球菌が優位を占 めている．表 2 に過去 2 年間の両者の比較を示した，好 気性菌だけでみると, グラム陽性球菌と陰性桿菌は, 外 科ではそれぞれ $31.2 \%$ と $52.3 \%$ 亿対して耳鼻咽喉科 ではそれぞれ $40.2 \%$ と $36.0 \%$ である。.なお潇気性菌 では，外科は Bacteroides が優位を占めているのに対 し，耳鼻咽喉科では Peptococcus が最も多い
次に膿・分泌液からの菌の陽性率, 混合感染率の推移

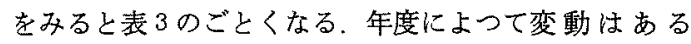
が，この10年間に特別な変動の傾向はなさそうである. な㧍 1 種の場合にしろ, 数種の場合にしろ, 常在菌の混 入の有無はわからない，材料採取時常在菌の混入の可能 性が大きいから，常在菌の混入むかなりあると考えられ る. 菌が 1 種のみ検出された場合， 2 種検出された場 
表 4 耳漏加らの菌の楅出状態

(1974年)

1 種の場合 (250例)

$\begin{array}{lc}\text { 黄色ブドウ球菌 } & 34.8 \% \\ \text { 表皮ブドウ球菌 } & 20.0 \\ \text { 緑 膿 菌 } & 12.0 \\ \text { Aspergillus } & 6.0 \\ \text { Corynebacterium } & 5.6\end{array}$

2 種の場合 (155例)

黄色ブドウ球菌 + 緑 膿 菌 $11.0 \%$

黄色ブドウ球菌 + Corynebacterium 8.4

黄色ブドウ球菌 ＋表皮ブドウ球菌 7.7

表皮ブドウ球菌 + Corynebacterium 7.7

表皮ブドウ球菌 + 緑 膿 菌 7.1

黄色ブドウ球菌 + Proteus mirabilis 4.5

〔黄色ブドウ球菌との組合せ $41.9 \%$

，表皮ブドウ球菌との組合せ 29.7

合，如何なる菌種が多いかを1974年 1 年間の耳漏につい てみると表 4 のごとくである、1 種のみの場合黄色ブド ウ球菌が最も多く，表皮ブドウ球菌がこれにつぎ，2種 の場合も黄色ブドウ球菌と他菌の組合せが最も多く, 表 皮ブドウ球菌と他菌の組合せがこれにつぐ.

緑膿菌の分離率は最近低下の傾向にあるが，耳鼻咽喉 科領域の感染症，とくに中耳炎ではいぜん重要な地位を 占めている，その血清型別を1974分離株42株について行 つたところ，5型が35.7\%で最も多く，8型がこれにつ いで $14.3 \%$ であつた，他の各種検查材料から分離された 緑膿菌の血清型とほぼ同様の傾向であつた。な挔緑澧菌 の中で，最近ムコイド型緑膿菌が注目されている2)が， 1973，1974年 2 年間に緑膿菌 294 株中 5 株ムコイド型が 検出された．非ムコイド型と比べて如何なる病原的意義 があるかは今後の課題である。な招少数例ながら他の Pseudomonas 属 (P. maltophilia, P. stutzeri, P. putre-
表 5 咽頭粘液の病原菌の変遷

\begin{tabular}{|c|c|c|c|}
\hline 菌 & $\begin{array}{c}1961 \\
? \\
1964\end{array}$ & $\begin{array}{r}1971 \\
72\end{array}$ & $\begin{array}{r}1973 \\
74\end{array}$ \\
\hline 黄色ブドウ球菌 & 30.4 & 13.7 & 13.1 \\
\hline 溶血 連 鎖 球 菌 & 20.4 & 8.8 & 7.0 \\
\hline 肺 炎 球 菌 & 4.5 & 1.2 & 1.6 \\
\hline 腸 球 菌 & 0.1 & 2.6 & 3.6 \\
\hline$シ ゙ フ テ リ ア$ 菌 & 0.5 & 0 & 0 \\
\hline Klebsiela & 7.0 & 14.3 & 15.3 \\
\hline 大＼cjkstart腸 & & 5.3 & 4.6 \\
\hline Enterobacter & & 6.3 & 7.3 \\
\hline Citrobacter & & 0.6 & 0.6 \\
\hline Serratia & 12.2 & 0.3 & 1.2 \\
\hline $\begin{array}{c}\text { Proteus Vulgaris } \\
\| \quad \text { mirabilis }\end{array}$ & & 0.6 & 1.2 \\
\hline その他の Proteus & & 0.8 & 0.5 \\
\hline インフルェンザ菌 & & 5.4 & 4.7 \\
\hline その他の Haemophilus & 14.9 & 28.9 & 25.5 \\
\hline 緑＼cjkstart膿 & 3.1 & 6.1 & 7.5 \\
\hline Acinetobacter & & 1.6 & 1.4 \\
\hline その他のグラム陰性桿菌 & 1.2 & 1.7 & 2.6 \\
\hline 真 & 5.7 & 1.8 & 2.5 \\
\hline 検 出 株 数 & 943 & 3,218 & 4,269 \\
\hline
\end{tabular}

主要常在細菌は除く.

faciens, P. putida, P. alcaligenes), Seratia などが検出 されておりこれらは各種抗生物質に耐性のものが多 く，今後増加の可能性も考えられる。

次に咽頭炎, 扁桃炎からの検出菌の推移を眺めてみ る. 表 5 にみるように，溶血連鎖球菌の検出率の低下は 顕著である．溶血連鎖球菌以外の菌が原因となる場合が 增加したのか，あるいは早期に抗生物質が使用されるた

表 6 咽頭溶血連鎖球菌の群別・型別

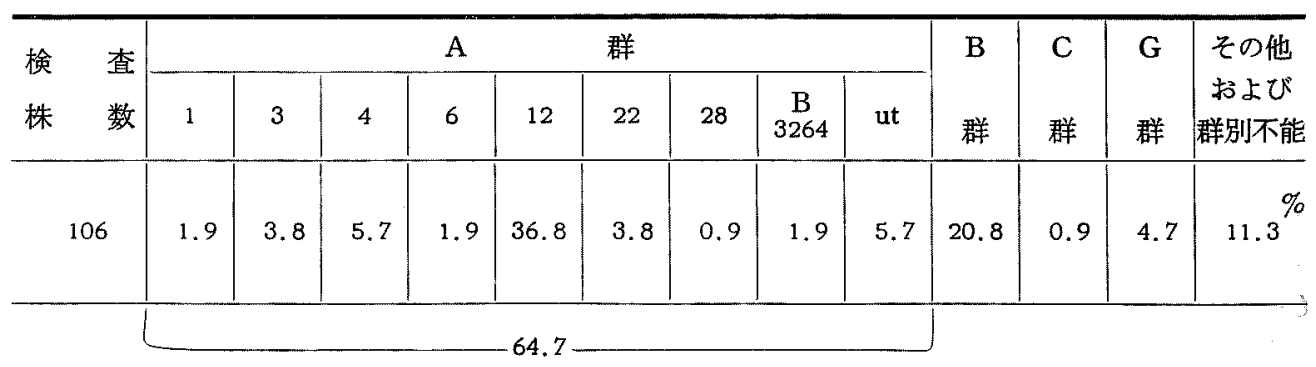

（1973，1974年分離株） 
め溶血連鎖球菌の検出率が低下したのかわからない，恐 らく原因は後者ではなかららか. 溶血連鎖球菌の群別, 型別の結果は表 6 のごとく，A群で柱12型が最も多く， A群以外ではB群が約 $21 \%$ と多いことが注目される，B 群の扁桃炎, 咽頭炎の原因菌としての役割，またいわゅ る病巣感染における役割については今後の研究課題であ るが，B群の多くは Streptolysin O を産生しないから， $\mathrm{ASO}$ 価注感染しても上昇しないことは留意すべきであ る.

\section{2. 原因菌の検查方法について}

膿・分泌液の場合は，その中に含ま机るすべての細 菌, 真菌が検出される方法を講じなければならない 分 離培地として，(1)血液塞天平板（基磷培地として heart infusion agar など良質のものを用いる）は不可欠で， (2)腸内細菌, 緑膿菌の検出し易くするための BTB 乳糖 寒天平板（または他の腸内細菌用平板培地），および(3) 混合感染が多く,グラム陰性桿菌とグラム陽性菌が混在 する場合，グラム陽性菌が分離しにくいことが多いの で，グラム陽性菌の選択培地として PEA (phenylethanol）加血液寒天平板が必要である。 またインフルエン
ザ菌は羊血液を用いた血液寒天には発育しにくいので， (4)チョコレート寒天平板を欠かせない（ウサギ血液を用 いた場合はチョコレート寒天は必ずしも用いなくともよ い).さらに嫌気性菌分離のため，(5)血液加 liver Veal 寒天平板または GAM 寒天平板，および(6)混在する可 能性のあるProteus 属などの発育を抑制して検出を容易 にするため PEA 加血液寒天平板を用いる。この(5)，(6) は呼気的に培養する，その上，材料中に菌数が少い場合 を考虑して，好気性菌と嫌気性菌の増菌培地として，(7) 臨床用チオグリコレート培地（または GAM 半流動培 地）を併用する。なお培養に先立って材料のグラム染色 標本を作成，鏡検することはいらまでもない

嫌気性培盖はふつう48時間行う。したがつて好気性 菌, 嫌気性菌が混在する材料の場合には，同定検查が終 るまでには数日を要することもまれでなく，感受性検查 は分離培養が終つたところで開始するが，結果が出るま でに，検查開始日から 4，5 日を要する。この日数を短 縮することが今後の課題である。

扁桃，咽頭粘液の検查では，ジフテリアの激減した今 日，溶血連鎖球菌の検出が第 1 目標である，表 5 に見ら

表 7 黄色ブドウ球菌の抗生物質感受性

\begin{tabular}{|c|c|c|c|c|c|c|c|c|c|c|c|c|c|}
\hline \multirow{2}{*}{ 薬 } & \multirow{2}{*}{$\begin{array}{l}\text { 検 查 } \\
\text { 株 数 }\end{array}$} & \multicolumn{12}{|c|}{ M I C $(\mu \mathrm{g} / \mathrm{ml})$} \\
\hline & & $\leqq 0.10$ & 0.20 & 0.39 & 0.78 & 1.56 & 3.13 & 6.25 & 12.5 & 25 & 50 & 100 & $>100$ \\
\hline$P C-G$ & 108 & 12.1 & 2.8 & 9.3 & 14.8 & 11.1 & 2.8 & 7.4 & 6.5 & 3.7 & 13.0 & 10.2 & 6.5 \\
\hline$A B-P C$ & 108 & 2.8 & 8.3 & 2.3 & 9.3 & 17.6 & 11.1 & 6.5 & 7.4 & 5.6 & 5.6 & 14.8 & 8.3 \\
\hline $\mathrm{MD} I-\mathrm{PC}$ & 215 & 1.4 & 33.0 & 60.5 & 1.9 & 1.4 & 0.5 & & & & 0.5 & 0.5 & 0.5 \\
\hline CER & 230 & 50.4 & 31.3 & 11.7 & 4.4 & & 0.9 & 0.4 & 0.9 & & & & \\
\hline $\mathrm{CET}$ & 218 & 0.5 & 20.2 & 70.6 & 6.4 & & & & 0.5 & 0.5 & 1.4 & & \\
\hline $\mathrm{CEZ}$ & 216 & & 2.3 & 22.2 & 54.6 & 18.1 & 0.5 & & & 0.5 & 0.9 & 0.9 & \\
\hline EM & 216 & 20.8 & 28.7 & 0.5 & & & 1.9 & & & & & & 48.2 \\
\hline $\mathrm{J} \mathrm{M}$ & 108 & & & 2.8 & 48.2 & 13.0 & 3.7 & & 0.9 & & & & 31.5 \\
\hline $\mathrm{LCM}$ & 160 & & 1.3 & 3.1 & 42.5 & 15.0 & 1.9 & 0.6 & & 0.6 & 0.6 & & 34.4 \\
\hline C LDM & 187 & 54.0 & 10.2 & 1.1 & & & & & 0.5 & & & 0.5 & 33.7 \\
\hline $\mathrm{SM}$ & 182 & & & 0.6 & 3.3 & 11.0 & 41.2 & 6.6 & 1.1 & 2.2 & 11.0 & 8.8 & 14.3 \\
\hline $\mathrm{KM}$ & 188 & & 0.5 & 2.7 & 46.8 & 18.6 & 3.7 & 0.5 & & & & & 27.1 \\
\hline $\mathrm{GM}$ & 188 & 24.5 & 55.9 & 18.1 & 1.6 & & & & & & & & \\
\hline DKB & 188 & 3.7 & 51.1 & 34.0 & 8.5 & & 0.5 & & & & 1.1 & 0.5 & 0.5 \\
\hline $\mathrm{CP}$ & 188 & & & & & 8.0 & 56.9 & 8.0 & & 1.1 & 11.2 & 14.4 & 0.5 \\
\hline TC & 188 & 6.9 & 40.4 & 10.6 & 2.7 & 2.7 & 0.5 & & & 2.7 & 0.5 & 8.0 & 25.0 \\
\hline
\end{tabular}


表 8 表皮ブドウ球菌の抗生物買感受性

\begin{tabular}{|c|c|c|c|c|c|c|c|c|c|c|c|c|c|}
\hline \multirow{2}{*}{ 薬 } & \multirow{2}{*}{$\begin{array}{ll}\text { 検 } & \text { 査 } \\
\text { 株 } & \text { 数 }\end{array}$} & \multicolumn{12}{|c|}{ M I C $(\mu \mathrm{g} / \mathrm{ml})$} \\
\hline & & $\leqq 0.10$ & 0.20 & 0.39 & 0.78 & 1.56 & 3.13 & 6.25 & 12.5 & 25 & 50 & 100 & $>100$ \\
\hline$P C-G$ & 73 & 12.4 & 9.6 & 9.6 & 2.7 & 6.9 & 5.5 & 9.6 & 2.7 & 5.5 & 9.6 & 21.9 & 4.1 \\
\hline$A B-P C$ & 73 & 9.6 & 5.5 & 15.1 & 6.9 & 5.5 & 9.6 & 4.1 & 4.1 & 4.1 & 12.3 & 16.4 & 6.9 \\
\hline MD I - P C & 73 & 2.7 & 27.4 & 4.1 & 11,0 & 16.4 & 9.6 & 2.7 & 1.4 & 2.7 & & & 31.9 \\
\hline CER & 73 & 41.1 & 13.7 & 5.5 & 11.0 & 4.1 & 5.5 & 1.4 & 4.1 & 8.2 & 5.5 & & \\
\hline CET & 73 & 6.9 & 16.4 & 16.4 & 12.3 & 31.9 & 2.7 & 2.7 & 1.4 & 2.7 & 8.2 & 8.2 & \\
\hline $\mathrm{CEZ}$ & 73 & 1.4 & 6.9 & 13.7 & 15. 1 & 17.8 & 15.1 & 5.5 & 2.7 & 2.7 & 1.4 & 8.2 & 9.6 \\
\hline $\mathrm{EM}$ & 73 & 21.9 & 17.8 & 1.4 & 2.7 & 2.7 & 4.1 & & & 1.4 & & 1.4 & 46.6 \\
\hline $\mathrm{JM}$ & 73 & & & 17.8 & 16.4 & 16.4 & 5.5 & & 1.4 & & & & 42.5 \\
\hline $\mathrm{LCM}$ & 73 & & 6.9 & 31.9 & 9.6 & 1.4 & 8.2 & 4.1 & & 2.7 & & 2.7 & 42.5 \\
\hline C L DM & 73 & 45.2 & 9.6 & 1.4 & 1.4 & & & & & & & & 42.5 \\
\hline $\mathrm{SM}$ & 73 & & & 8.2 & 17.8 & 2.7 & 4.1 & 1.4 & 6.9 & 13.7 & 20.6 & 6.9 & 17.8 \\
\hline $\mathrm{KM}$ & 73 & 4.1 & 23.3 & 5.5 & 5.5 & 2.7 & & 4.1 & 1.4 & 6.9 & 31.9 & 13.7 & 11.0 \\
\hline GM & 72 & 93.1 & 2.8 & & 4.2 & & & & & & & & \\
\hline DK B & 72 & 86.1 & 1.4 & 8.3 & 4.2 & & & & & & & & \\
\hline $\mathrm{CP}$ & 72 & & & & 5.6 & 18.1 & 22.2 & 1.4 & 1.4 & 2.8 & 36.1 & 11.1 & 1.4 \\
\hline $\mathrm{TC}$ & 72 & 6.9 & 27.8 & 11.1 & 9.5 & 2.8 & & & 1.4 & 5.6 & 15.3 & 6.9 & 12.5 \\
\hline
\end{tabular}

(1972. 10-1975.3)

れる黄色ブドウ球菌, Klebsiella, Haemophilus 属が如 何なる臨床的意義を持つか不明の場合が多いが，これら も検出できるように，私どもは分離培地として血液寒天 平板, チョコレート寒天平板, BTB 乳糖寒天平板, 覀 テルル酸塩加血液寒天平板を併用している. 血液寒天平 板はローソク法, あるいは嫌気的に培養すると溶血連鎖 球菌の検出が容易になる。な拉材料採取後直ちに分離培 養する場合には，溶血連鎖球菌の選択分離培地 (Pike 培 地など）を併用する必要は必ずしもないようである。

膿・分泌液の場合, 検查結果だけから原因菌か常在菌 の混入が注別できない 常在菌を混入させない材料の 採取法が考えられなければならない，また材料採取後直 ちに検查できない場合，保存中に死滅あるいは増殖する 菌があるので，保存方法にほ注意を要する。

2 種以上菌が検出された場合, どの菌が最も重要な役 割をしているかは，判断できないことが多い．菌数が多 い方が重要であるとも限らない.

\section{3. 主要病原菌の抗生物質感受性の現況}

1) ブドウ球菌

黄色ブドウ球菌，表皮ブドウ球菌それぞれについて，
耳鼻咽喉科のそれと全科のとで感染率に差があるかどう かを，1973，1974年分離株のディスク法の結果を集計, 比較したところ大差がなかつたので，耳鼻咽喉科由来と 限らずこの 2,3 年の間に臨床材料から分離・保存した ブドウ球菌の感受性を, 寒天平板希彩法 ${ }^{3}$ で測定した。 表 7，8に結果を示す 黄色ブドウ球菌は，MDI-PC, セファロスポリン剂, GM, DKB に強い感受性を示す が，GM 除いてはすでに耐性株と考えられるものが低 率ながら認められる，黄色ブドウ球菌のわが国に㧍ける 全国的な抗生物質感受性の推移については，御旅屋")の 報告があるので参照されたい 表皮ブドウ球菌の場合も 黄色ブドウ球菌と同様であるが，MDI-PC，七ファロス ポリン剂耐性菌が多かつた。

2) 溶血連鎖球菌

主として扁桃，咽頭材料から過去 2 年間に分離した株 について希橎法で検査した結果，A，C，G群は PCG の $0.025 \mu \mathrm{g} / \mathrm{ml}$, CER の $0.05 \mu \mathrm{g} / \mathrm{ml}$ で発育を阻止され， B 群はこれら 3 群に比しやや感性度は悪かつたが，両剤 の $0.10 \mu \mathrm{g} / \mathrm{ml}$ で全株発育を阻止された．TC 耐性菌は 各群にみられ，とくに A，B群の70\%以上が TC 耐性で 
表 9 A 群溶血連鎖球菌の菌型別 CP, TC, EM 感性率

（1973，1974年分離株）

\begin{tabular}{|c|c|c|c|c|}
\hline 型 & 検查株数 & $\mathrm{CP}$ & TC & $\mathrm{EM}$ \\
\hline 1 & 2 & 50.0 & 50.0 & $50.0 \%$ \\
\hline 3 & 4 & 33.3 & 33.3 & 100 \\
\hline 4 & 7 & 100 & 14.3 & 100 \\
\hline 6 & 2 & 50.0 & 50.0 & 100 \\
\hline 12 & 47 & 31.9 & 10.6 & 40.4 \\
\hline 22 & 4 & 100 & 66.7 & 100 \\
\hline$\underset{3264}{\mathrm{~B}}$ & 2 & 100 & 100 & 100 \\
\hline
\end{tabular}

$\mathrm{CP} \cdots \mathrm{MIC} \quad 6.25 \mu \mathrm{g} / \mathrm{ml}$ 以下

TC…MIC $1.56 \mu \mathrm{g} / \mathrm{ml}$ 以下 を感性とした.

EM $\cdots \mathrm{MIC} \quad 0.39 \mu \mathrm{g} / \mathrm{ml}$ 以下

あつた。 CP 耐性はA群の50\%，B群の約 $20 \% ， \mathrm{G}$ 群の 25\%にみられた。 EM 而性については最近報告が数多く みられるが，A群の40\%に耐性菌がみられた，B群， G 群には極く僅かで，C群には見らはなかつた．A群の菌 型別に CP, TC, EM 感性率をみると表 9 のごとくで, 耐性菌の多いのは流行菌型の12型であることが明らかで ある。なお EM 耐性株は JM， LCMにも耐性であった。

3) Corynebacterium

ジフテリア菌以外の Corynebacterium 属の種の同定は 行つていないから一括して取扱わざるを得ないが，最近 2 年間に耳鼻咽喉科の材料から検出されたものの感受性 をディスク法で測定した結果を10表に示した、ディスク 法は誤差が大きいが，大体の傾向を知ることはできる。
表10 耳鼻咽喉科領域の膿・分泌液上り分離した Corynebacterium の抗生物翼感性率

( 3 濃度ディスク法)

\begin{tabular}{c|c|c|c}
\hline 薬 剂 & 1973 年 & 1974 年 & \multicolumn{1}{|c}{ 計 } \\
\hline P C-G & $82.8^{\%}$ & $87.0^{\%}$ & $85.5^{\%}$ \\
MC I-P C & 68.8 & 61.7 & 64.4 \\
A B-P C & 95.7 & 93.5 & 94.3 \\
C B-P C & $91.8^{*}$ & - & 91.8 \\
S B-P C & $93.8^{* *}$ & 96.1 & 95.5 \\
\hline C E R & 96.8 & 98.7 & 98.0 \\
\hline EM & 76.3 & 76.6 & 76.5 \\
J M & 74.2 & 74.7 & 74.5 \\
LM & 73.1 & 76.0 & 74.9 \\
L CM & 73.1 & 74.0 & 73.7 \\
\hline SM & 53.8 & 58.4 & 56.7 \\
KM & 54.8 & 53.2 & 53.8 \\
GM & 92.5 & 86.4 & 88.7 \\
\hline C P & 76.3 & 71.4 & 73.3 \\
\hline T C & 84.9 & 85.1 & 85.0 \\
\hline 検 查 株 数 & 93 & 154 & 247 \\
\hline
\end{tabular}

*...49株，**..48株のみ検查

卅，州感性とした。

2 年間で耐性菌の増加は認められず, SM, KM, MCI-PC 以外の薬郕に対しては70\%以上が感性である．とくに広 域合成ペニシリン剂，セファロスポリン剤，GMには90 \%以上が感性である。

表11 緑膿 菌の抗生物質感受性 (755株)

\begin{tabular}{|c|c|c|c|c|c|c|c|c|c|c|c|c|}
\hline \multirow{2}{*}{ 薬，郕 } & \multicolumn{12}{|c|}{ M I C $(\mu \mathrm{g} / \mathrm{ml})$} \\
\hline & $\leqq 0.39$ & 0.78 & 1.56 & 3.13 & 6.25 & 12.5 & 25 & 50 & 100 & 200 & 400 & $>400$ \\
\hline$S B-P C$ & 0.3 & 1.1 & 0.7 & 0.8 & 0.7 & 7.3 & 35.5 & 35.5 & 8.9 & 4.9 & 2.3 & $2.3^{\%}$ \\
\hline$S M$ & 0.1 & 1.3 & 1.5 & 4.1 & 27.6 & 22.8 & 7.7 & 1.7 & 0.1 & 0.3 & 1.3 & 31.5 \\
\hline $\mathrm{KM}$ & & 0.4 & & 0.1 & 1.1 & 1.6 & 8.0 & 21.7 & 36.6 & 20.3 & 3.8 & 6.5 \\
\hline GM & 23.3 & 39.2 & 23.8 & 9.1 & 2.4 & 1.2 & 0.7 & & 0.3 & & & \\
\hline $\mathrm{DKB}$ & 53.4 & 39.1 & 4.4 & 0.9 & 0.4 & 0.7 & 0.3 & 0.7 & & & 0.3 & \\
\hline TOB & 84.6 & 10.2 & 2.5 & 0.8 & 0.5 & 1.1 & & & & 0.3 & & \\
\hline $\mathrm{BB}-\mathrm{K} 8$ & 3.3 & 15.4 & 50.7 & 24.0 & 4.4 & 1.2 & 0.9 & 0.1 & & & & \\
\hline C L & 0.3 & 0.5 & 3.3 & 30.3 & 57.2 & 8.0 & 0.3 & & 0.1 & & & \\
\hline P L-B & 2.0 & 22.0 & 70.7 & 4.9 & 0.1 & 0.3 & & & & & & \\
\hline
\end{tabular}


表12 菌の種類による感受性ディスクの選択

$\bigcirc \cdots$ 必要, $\times \cdots$ 不要, 空欄は必要に応して加える

\begin{tabular}{|c|c|c|c|c|c|c|c|c|}
\hline \multirow[b]{2}{*}{ 薬 } & \multirow[b]{2}{*}{ 剂 } & \multicolumn{2}{|c|}{ グラム陽性球菌 } & \multirow{2}{*}{$\begin{array}{l}\text { グラム陽 } \\
\text { 性桿菌 }\end{array}$} & \multirow{2}{*}{$\begin{array}{l}\text { グラム陰 } \\
\text { 性球菌 }\end{array}$} & \multicolumn{2}{|c|}{ グラム陰性桿菌 } & \multirow[b]{2}{*}{ 嫌気性菌 } \\
\hline & & $\begin{array}{l}\text { ブドウ球 } \\
\text { 菌 }\end{array}$ & \begin{tabular}{|l} 
連鎠球菌 \\
\end{tabular} & & & $\begin{array}{l}\text { 腸内細菌 } \\
ヘ モ ュ ィ \\
\text { ールス }\end{array}$ & $\begin{array}{l}\text { 緑澧菌, } \\
\text { 類似菌 }\end{array}$ & \\
\hline & $\begin{array}{l}\mathrm{PC}-\mathrm{G} \\
\mathrm{P} E-\mathrm{P} C \\
\mathrm{P} P-\mathrm{P} C\end{array}$ & $O^{\prime \prime}$ & 0 & 0 & 0 & $x$ & $x$ & $\mathrm{O}$ \\
\hline $\begin{array}{l}\text { ペニシリナーゼ } \\
\text { 耐性 } \\
\text { ペリシ }\end{array}$ & $\begin{array}{l}\text { MP I-P C } \\
\text { MC I-P C } \\
\text { MD I-P C } \\
\text { MF I-P C }\end{array}$ & 0 & & & & & & \\
\hline 広域 & $\begin{array}{l}A B-P C \\
A M-P C\end{array}$ & 0 & 0 & 0 & 0 & 0 & $x$ & 0 \\
\hline ペニシリン & $\begin{array}{l}\text { C B-P C } \\
\text { S B-P C }\end{array}$ & $\mathrm{O}$ & $x$ & & ) & 0 & 0 & \\
\hline \multirow{3}{*}{$\begin{array}{l}\text { セファロスポり } \\
\text { ン剤 }\end{array}$} & $\begin{array}{l}\text { CER } \\
\text { CET }\end{array}$ & & & & & $\cap$ & Y & $\cap$ \\
\hline & $\begin{array}{l}\text { CE } \\
\text { CEX }\end{array}$ & 0 & $U$ & 0 & 0 & $U$ & $x$ & 0 \\
\hline & $\begin{array}{l}\mathrm{C} \\
\mathrm{T}\end{array}$ & \} 0 & 0 & $\mathrm{O}$ & 0 & 0 & & 0 \\
\hline $\begin{array}{c}\text { テトラ } \\
\text { サイクリン } \\
\text { 郕 }\end{array}$ & $\begin{array}{l}\text { TC } \\
\text { DMC T } \\
\text { DOTC } \\
\text { MTC }\end{array}$ & 0 & 0 & 0 & $\mathrm{O}$ & 0 & & 0 \\
\hline アミノグリコシ & $\begin{array}{l}\text { SM } \\
\text { KM }\end{array}$ & 8 & $\begin{array}{l}x \\
x\end{array}$ & & & 8 & & $\stackrel{x}{x}$ \\
\hline ッド剤 & $\begin{array}{l}\text { GM } \\
\text { DKB }\end{array}$ & \} 0 & $x$ & 0 & & 0 & 0 & $x$ \\
\hline $\begin{array}{c}\text { マクロライド } \\
\text { および } \\
\text { 類似郕 }\end{array}$ & $\begin{array}{l}\text { EM } \\
\text { OL } \\
\text { LM } \\
\text { S PM } \\
\text { JM } \\
\text { LCM } \\
\text { CLDM }\end{array}$ & 0 & $>0$ & 10 & $>0$ & $x$ & $x$ & $>0$ \\
\hline $\begin{array}{l}\text { ポリペブタイド } \\
\text { 剂 }\end{array}$ & 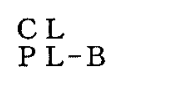 & \}$x$ & $x$ & $x$ & $x$ & 0 & 0 & $x$ \\
\hline
\end{tabular}

4) インフルエンザ菌

抗菌力の強い薬剂は $\mathrm{AB}-\mathrm{PC}, \mathrm{GM}, \mathrm{CP}, \mathrm{TC}$ で, CL, NA，KM などがこれにつぐ. 最近 AB-PC, TC 酎性菌 も認められる。セファロスポリン刻，マクロライド戍は 抗菌力が弱、

\section{5) 腸内細菌}

Proteus 属 (P. Vulgaris, P. mirabilis, P. morganii, P. rettgeri, P. inconstans) は菌種によつて感受性に相 量があることに注意しなければならない．P. mirabilis は AB-PC, 七ファロスポリン斉に感性菌が 50\% 近く認 められるに対し，P. Vulgaris はほとんどが両阂に耐性 て, P. morganii, P. mirabilis, P. inconstans も大部分
が両剤に耐性である、CB-PC, SB-PC は AB-PC に比へ ると抗菌力が強く，GM は抗菌力が著しく強く, 而性菌 は少ない. DKB は GM に比べる抗菌力はやや劣る.

Enterobacter 最近増加の傾向にあり, Serratia 増 加の可能性があるが，各種抗生物質に面性のものが多 い $\mathrm{GM}$ が抗菌力が強く, DKB がこれにつぐ.

Klebsiella, 大腸菌については既に多くの報告があるの で省略する.

\section{6) 緑呩菌および他の Pseudomonas 属}

耳鼻咽喉科材料と限らず各種臨床材料から昨年 1 年間 に分離した緑膿菌の感受性測定結果を表11 に示寸. SB$\mathrm{PC}$ は CB-PC よりもやや抗菌力が強いことが知られて 
表13 ディスク法の結果からの抗生物質の選び方

1. ディスク法は多数の常用抗生物質のらちから当 該菌に有効と考えられるいくつかの菒殽を選び出 ナスクリーニング検查である.

2. 卅または井の薬剤の中から病原菌の種類薬剤の 投与方法および量, 病巣への浸透度などを考えて 選択する. 直接局所に高濃度を作用させらるとき は十の薬剤でもよいことがある。

3. ディスク法は抗生物質の発育阻止力を推定する 方法である。殺菌力はわからない，慢性感染症で は殺菌力が強いものがよいといわれる。

4. 抗生物質の 2 剂以上の併用効果をディスク法で 検查することはむつかしい

いるので，ここでは SB-PC を用いた．他の常用抗生物 質には大部分の菌株が而性であるがので，測定しなかっ た， GM その他抗緑膿菌用アミノグリコシッド剂が強い 抗菌力を持つが，耐性菌も僅かながら認められる。

他の Pseudomonas 属の感受性は緑膿菌とは必ずしも 同じではなく，Ps. maltophilia に対しては GM, DKB なども抗菌力は弱い.

7) 嫌気性菌

嫌気性菌はアミノグリコシッド剤を除く常用抗生物質 の大部分に感性で，耐性菌は少ないと言われていたが， 最近耐性化が注目されるようになつた があるが TC 耐性菌が増加し，また Bacteroides では各 種抗生物質耐性菌が多くなつた，一般に CP 耐性菌は少 なく，CLDM には耐性菌の增加の傾向があるが，抗菌 力は他剤に比べて強い.

\section{4. ディスク法による感受性検査の問題点}

1) 直接法について

常在菌を含む可能性の少ない澧・分泌液で，塗抹陽性 の場合, 直接法で感受性検查を行うと, 材料採取後 24 時 間で結果がわかる利点がある。しかし 2 種以上の菌が混 在する場合には，成績が出ないことが多い，かかる場合 は間接法で各菌種についてやりなおさなければならな い.また直接法の場合，菌が 1 種類であっても接種菌量 の調節がむつかしいため成績の誤差が大きい.
2) 日常検查におりる薬剤の組合せ

検查施設においては，検出された菌の種類によつて， 使用するディスクの種類を定めている，元来無効の薬剤 を使用する必要はなく，また交差耐性の認められる薬㓮 群では，その中の 1 つを代表とすればよい勿諭その薬 鼡群の中でも, 抗菌力には差はあつても，ディスク法は いわばスクリーニング検查であるから，いずれか 1 鼡に ついて検查すればよい，菌の種類とディスクの組合せの 1 例を表12に示す。

3）感受性検查成績の読み方について

ディスク法の結果からの抗生物質の選び方の要点は表 13に示すごとくである。な拉詳細については拙著矿〉を参 照されたい。

4) 今後の問題

ディスク法は単なるスクリーニング検査であるから， できるだけ正確に臨床効果の予測できる方法が 望まれ る. 膿・分泌液中の抗生物質の濃度測定の日常検查化と 希䣋法による感受性検查の自動化など，まず検査課題で はなかららか。

（終りに本講演の機会を与えられた山本想会長, 座長の 高須照男教授に感謝する。な拉本文中に述べた諸統計。 研究成績は当教室岡田淳助手, 中検小栗豊子技師に上る ものである。)

\section{文献}

1) 更科兼蔵：急性中耳次の細菌学的研究. 衛生学伝染 病学雑誌, 37, 107-148, 1941.

2 ）山中太木 - 薮内英子編 : Pseudomonas 感染症 の 基 礎々臨床，10-21，日水製薬，1973.

3) MIC 測定法改訂委員会 : MIC 測定法改訂について. Chemotherapy, 22, 1126-1128, 1974.

4) Otaya, H.: Sensitivity of Staphylococcus aureus and Escherichia coli ito antibiotics. $V, J$. Antibiotics, 27, 686-695, 1974.

5 ) 小栗豊子・小酒井望：嫌気性菌の各種抗生物質に対 する感受性の推移. J.J. Antibiotics, 27, 286-295, 1974. 6) 小酒井望: 薬剤感受性々臨床効果, 感染症学雅誌, 44, 143-145, 1970. 